\title{
PERUMUSAN DAN PENGEMBANGAN TUJUAN INSTRUKSIONAL KHUSUS DI SDN SARAKAN 2
}

\author{
Ina Magdalena ${ }^{1}$, Tasya Farlidya ${ }^{2}$, Winda Yuniar ${ }^{3}$ \\ Universitas Muhammadiyah Tangerang \\ inapgsd@gmail.com, tasyafarlidya@gmail.com
}

\begin{abstract}
This study aims to determine the writing of specific instructional objectives at SDN $S A R A K A N$ 2. The method that will be used at the time of research is descriptives method through a qualitative approach. The object to be studied is a grade 3 teacher at SDN SARAKAN 2. The process to be used at this time is interview and documentation techniques. The formulation of specific learning objectives includes only learners and behavior. The teaching method in genral the teacher applies the lecture method using the powerpoint slide media which takes place when online learning begins and online question and answer wuestions are the given online and the assignment is collected. Special instructional management is manidested in the presence of a coordinator who is responsible for equipment and supplies such as primary school teachers or commonly referred to as homeroom teachers, who have design favtors, namely: 1) Espertise in designing online-based learning; 2) Realization of teacher training; 3) The skill of applying concepts to new situations in different ways; 4) Make the school a learning organization; 5) The school is able to manage in planning, organizing, coordinating and supervising; 6) The ability to solve problems with systematic step in learning; 7) Skill to elaborate and evaluate learning outcomes.
\end{abstract}

Keywords: Assessment, Special Instructional, Learning Design.

\begin{abstract}
Abstrak : Penelitian ini bertujuan untuk mengetahui Menulis tujuan instruksional khusus di SDN SARAKAN 2. Method yang akan digunakan pada saat penelitian yaitu metode deskriptif melalui pendekatan kualitatif. Objek yang akan diteliti yaitu seorang guru kelas 3 SDN SARAKAN 2. Proses yang akan digunakan pada kali ini yakni teknik wawancara dan dokumentasi. Perumusan tujuan pembelajaran khusus hanya meliputi peserta didik dan perilaku. Metode mengajar umumnya guru menerapkan metode ceramah menggunakan media slide power pont yang berlangsung saat pembelajaran online dimulai dan Tanya jawab melalui online lalu penugasan pun diberikan secara online serta pengumpulan tugasnya. Pengelolaan instruksional khusus diwujudkan adanya coordinator yang bertanggung jawab atas peralatan dan perlengkapan seperti guru sd atau biasa disebut dengan wali kelas, memiliki factor-faktor yang merancang yaitu :1) Keahlian merancang pembelajaran berbasis online; 2) Perwujudan pelatihan guru; 3) Keahlian menerapkan konsep pada situasi baru dengan cara yang berbeda; 4) menjadikan sekolah sebagai organisasi
\end{abstract}


belajar; 5) Sekolah sanggup mengelola dalam merencanakan ,mengorganisasikan , pengkoordinasikan dan supervise; 6) kemampuan untuk memecahkan persoalan dengan langkah yang sitematis dalam pembelajaran; 7) Keahlian untuk mengelaborasi dan mengevaluasi hasil belajar.

Kata Kunci : Penilaian, Instruksional Khusus, Desain Pembelajaran

\section{PENDAHULUAN}

Sejak diberlakukannya kurikulum 1975, yang waktu itu dikenal dengan sebutan Pembakuan Kurikulum, para guru diwajibkan menggunakan Tujuan Instruksional Khusus (TIK) dalam melaksanakan tugasnya dari mulai perencanaan pengajaran, pelaksanaan proses belajar-mengajar sampai evaluasi pengjaran. Kewajiban itu merupakan implikasi dari penggunaan prinsip objective oriented sebagai salah satu asas pengembangan kurikulum. Penerapan prinsip berorientasi pada tujuan ini Nampak pada kurikulum 1975 dengan dicantumkannya berbagai jenis tujuan yang tersusu secara hierakis, dari mulai tujuan Pendidikan nasional, tujuan institusional, tujuan kurikuler sampai ke tujuan instruksional umum. Atas dasar tujuan-tujuan itu, guru diwajibkan mengembangkan tujuan instruksional khusus untuk diusahakan pencapaiannya pada proses belajar-mengajar yang diselenggarakannya. Tujuan isntruksional khusus itu menjadi tujuan antara untuk mencapai tujuan yang berada diatasnya.

Desain pembelajaran harus dilakukan dengan memperhatikan kondisi-kondisi dimana pembelajaran itu harus dilaksanakan. Desain pembelajaran merupakan suatu sistem. Dengan kata lain desain pembelajaran ini dikonstruksi melui tahap demi tahap, diawali dengan informasi yang mencerminkan tujuan yang sebelumnya telah diidentifikasi. (Gagne, Wager, Golas and Keller, 2005) dalam (Setyosari, Desain Pembelajaran, 2020). Desain instruksional tumbuh dan berkembang melalui pangaruh dari berbagai disiplin ilmu, baik yang tumbuh lebih dahulu maupun yang tumbuh bersamaan dengan desain instruksional sendiri atau teknologi Pendidikan.

Benny A.Pribadi (2010:18) mengemukakan bahwa penerapan desain instruksional bertujuan untuk menciptakan pembelajaran yang sukses, yaitu pembeljaran yang mampu membantu siswa mencapai kompetensi yang diinginkan. 
Proses pembelajaran mengalami pergeseran dari konvensional (tatap muka) menjadi digital atau online dengan alasan fenomena pemanfaatan teknologi dimasyarakat yang kian tinggi. Guru memiliki peran penting dan peranan sangat strategis dalam proses pembelajaran ini memiliki dampak pada kompetensi yang dicapai siswa (pengetahuan, sikap, keterampilan).

Bersumber dari penelitian di kelas 3 SDN SARAKAN 2 menghasilkan guru memposisikan diri dan menempatkan posisi siswa dalam pembelajaran. Sejalan dengan perkembangan ilmu pengetahuan maka proses pembelajaran harus berorientasi pada siswa belajar aktif (student active learning). Guru harus memberikan kesempatan kepada siswa untuk melakukan eksplorasi dalam pembelajaran.

\section{Teori Pengembangan Desain Instruksional}

Desain Instruksional merupakan pengembangan dalam menyusun suatu kegiatan pembelajaran secara sistemik untuk mencapai tujuan pembelajaran. Seels \& Richey didalam (Setyosari, Metode Penelitian dan Pembelajaran, 2013) berpendapat sebagai berikut, " Developmental research, as opposed to simple instructional development, has beeb defined as the systematic study of designing, developing abd evakuating instructional programs, processes and products that must meet the criteria of internal consistency and effecriveness." Berdasarkan hal tersebut penelitian pengembangan sebagaimana dibedakan dengan pengembangan pembelajaran sederhana, didefinisikan sebagai kajian sistematik untuk merancang, mengembangjan dan mengevaluasi program-program, proses, dan hasil pembelajaran yang harus memenuhi kriteria konsistensi dan keefektifan secara internal. Dari uraian tersebut dapat disimpulkan bahwa penelitian pengembangan merupakan kajian mengenai proses yang secara sistematik untuk merancang, mengembangkan dan menevaluasi pembelajaran yang melibatkan beberapa komponen yang bertujuan untuk mendesain sebuah desain pembelajaran yang efektif dan sesuai bagi peserta didik.

Menurut maduarti, dkk di dalam (Suparman, desain instructional, 2014) menyatakan bahwa "Pengembangan pembelajaran, desain system pembelajaran atau teknologi kinerja, sebenarnya istilah tersebut dapat saja menunjuk hal yang sama, desain pembelajaran." Hal tersebut mengartikan bahwa desain instruksional atau desain system pembelajaran mengartikan hal yang sama yaitu desain pembelajaran. 
Belakangan istilah instruksional sebagai pengajaran telah ditinggalkan dan berganti sebagai pembelajaran. Jika ditelusuri isilah pengajaran dan pembelajaran memang memiliki pengertian yang berbeda. Dalam pengajaran, Gagne mengemukakan bahwa pengajar berperan dan memfasilitasi terjadinya proses dan hasil belajar pada diri peserta didik. Pengajar adalah pihak yang aktif memfasilitasi peserta didik. Menurut Joice dan Weil, didalam pengajaran pengajar dan peserta didik secara bersama menciptakan lingkungan termasuk serangkaian tata nilai dan keyakinan yang dianggap penting untuk menyatakan pandangan tentang realitas kehidupan. (Suparman, Desain Instruksional Modern, 2012).

Dari definisi tersebut bahwa yang berperan aktif dalam proses pembelajaran adalah pengajar. Istilah pengajar menjadi kurang tepat karena menunjukkan dan menempatkan guru menjadi pelaku utama dan lebih dominan dalam proses mengajar. Dalam hal ini, tentu saja siswa menjadi pasif dan jadi pendengar yang baik. Setiap proses pembelajaran siswa disuguhkan materi pembelajaran, sementara guru berkerja keras memenuhi materi pelajaran sesuai dengan kurikulum yang berlaku.

Istilah pengajaran diganti dengan pembelajaran karena adanya kesadaran bahwa yang berperan aktif didalam kelas, yang mencari ilmu pengetahuan, serta yang lainnya adalah peserta didik tapi tidak pula untuk mengabaikan peran pengajar dalam proses pembelajaran. Pembelajaran adalah suatu rangkaian peristiwa yang mempengaruhi peserta didik atau pembelajar sedemikian rupa sehingga perubahan perilaku yang disebut hasil belajar terfasilitasi. Pembelajaran memilik makna bahwa serangkaian kegiatan pembelajaran itu dirancang terlebih dahulu agar terarah sesuai dengan yang diharapkan.

Dalam peraktiknya, istilah dari pengajar ataupun pembelajaran tetap digunakan meski istilah pengajaran perlu diganti dengan pembelajaran, karena pada konteksya makna dari keduanya tetap lebih mengedepankan peran aktif peserta didik dalam proses pembelajaran tanpa melupakan peran guru didalamnya.

Tujuan desain yang dikembangkan untuk membantu meyelesaikan kebutuhan belajar siswa dan kebutuhan mengajar guru yang interaksinya diwujudkan dalam proses pembelajaran. John Mc Neil (Sanjaya, 2009) bahwa penilaian instruksional khusus merupakan suatu siklus yang integral dengan pengembangan program, 
implementasi dan evaluasi. Mendesain diawali dengan studi kebutuhan memungkinkan hasilnya dapat dimanfaatkan secara optimal oleh individu yang memerlukannya terkait dengan pembelajaran berbasis khusus.

\section{METODE PENELITIAN}

Metode yang akan digunakan dalam penelitian yaitu metode kualitatif. Penelitian dilakukan dalam situasi yang wajar, data yang dikumpulkan umumnya bersifat kualitatif yaitu satu penelitian mengarah pada enam langkah penelitian, seminar pradesain, memasuki lapangan, pengumpulan data, dan analisis data. Penelitian kualitatif adalah penelitian yang menekankan pada pemahaman mengenai masalah-masalah dalam kehidupan sosial berdasarkan kondisi realistis yang holistis, kompleks, dan terperinci (Anggito, 2018). Metode penelitian kualitatif, Creswell (2008) dalam (Semiawan, 2010) mendefinisikannya sebagai suatu pendekatan atau penelusuran untuk mengeksplorasi dan memahami suatu gejala sentral. Pada penelitian ini proses pelaksanaannya dilakukan dengan cara wawancara. Dalam pengumpulan data penelitian kualitatif, wawancara lebih dipilih sebagai alat penelitian, karena di kondisi yang sedang pandemi ini sehingga tidak memungkinkan untuk observasi ke sekolah secara langsung.

Prosedur penelitian dimulai dengan penulis melakukan wawancara untuk mengetahui penulisan tujuan instruksional khusus (TIK) dalam perkembangan pembelajaran penelitian ini dilaksanakan di Sekolah Dasar kelas 3 di SDN SARAKAN 2 pada bulan Januari 2021.

Subjek dan objek penelitian yang akan diteliti adalah Guru dari kelas III (3) di SDN SARAKAN 2

\section{Teknik Dan Instrumen Pengumpulan Data}

Teknik Pengumpulan Data dilakukan menggunakan pendekatan kualitatif yakni memakai sistem Wawancara.

Wawancara adalah sebuah percakapan antar dua orang atau lebih, yang pertanyaannya diajukan oleh peneliti kepada subyek penelitian untuk dijawab pada penelitian kualitatif disebut juga wawancara. Wawancara mendalam boleh dilakukan dengan dua 
cara yaitu, wawancara sebagai strategi utama dalam mengumpulkan data dan wawancara sebagai strategi penunjang teknik lain dalam pengumpulan data. Wawancara merupakan metode yang pertama digunakan dibanging dengan alat dalam penelitian (Edi, 2009). Dengan sistem pendekatan terlebih dahulu dan sedikit demi sedikit melakukan wawancara. Kondisi ini dilakukan supaya objek peneliti lebih bebas menjawab pertanyaan secara fakta. Selama wawancara peneliti mengadakan komunikasi langsung secara lisan atau tatap muka dengan sumber data. Pada saat wawancara dilakukan dengan satu orang guru kelas 3 SDN SARAKAN 2. Dengan demikian tujuan pemilihan pendekatan kualitatif.

\section{Keabsahan Data}

Keabsahan data dalam suatu penelitian dapat juga dicapat dengan process pengumpulan data yang tepat yaitu dengan proses Triangulasi. Pengumpulan dengan tekinik Triangulasi adalah pengumpulan data dengan menggunakan berbagai macam teknik pengumpulan data. Data yang terkumpul dari berbagai macacam teknik itu, dibandingkan mencari persamaan dan perbedaannya, ditarik kesimpulannya, dirumuskan makna yang terkandung dari persitiwa yang terjadi.

1. Data Reduction (Reduksi Data)

Data yang terdapat dari penelitian yang bermacam-macam, dengan menyinkronkan beberapa teknik. Mereduksi data berarti merangkum, memilih hal-hal yang pokok, memfokuskan pada hal-hal yang serius, dicari tema serta polanya dan keluarkan yang tidak wajib.

2. Data Display (Penyajian Data)

Dalam penelitian kualitatif, penyajian data dapat dilakukan dalam rangkaian uraian singkat, bagan, hubungan antar teori, dan sebagainya.

3. Conclusion (Penarikan Kesimpulan)

Kesimpulan dalam penelitian kualitatif dapat berupa deskripsi atau gambaran suatu objek yang sebelumnya masih abstrak sehinggan setelah diteliti menjadi jelas. 
Berdasarkan pengertian di atas, dalam penelitian ini menggunakan teknik analisis data kualitatif. Terdapat tiga jalur analisis data yaitu data reduction (reduksi data), data display (penyajian data), dan conclusion (penarikan kesimpulan)

Data reduction, pada tahap ini dilakukan pemilihan tentang relevan tidaknya antara data dengan tujuan penelitian. Data yang diperoleh dari penelitian yang beragam dengan memadukan beberapa teknik. Informasi dari lapangan sebagai bahan mentah yang kemudian diringkas, disusun lebih sistematis, serta ditonjolkan pokokpokok yang penting sehingga lebih mudah dikendalikan. Setelah tahap mereduksi data selesai dilakukan, kemudian dilanjutkan dengan display data untuk dapat melihat gambaran keseluruhan atau bagian Bagian tertentu dari gambar keseluruhan. Pada tahap ini peneliti berupaya mengklasifikasikan dan menyajikan data sesuai dengan pokok permasalahan yang diawali dengan pengkodean pada setiap sub pokok permasalahan. Untuk memudahkan memperoleh kesimpulan dari lapangan, maka penyajian data bisa dilakukan dalam bentuk uraian singkat, bagan, serta hubungan antar teori.

Tahap ketiga dalam teknik analisis data menurut Miles and Huberman adalah Conclusion drawing/verification (penarikan kesimpulan) Kegiatan yang dimaksudkan untuk mencari makna data yang dikumpulkan dengan mencari hubungan, persamaan atau perbedaan. Penarikan kesimpulan dilakukan dengan jalan membandingkan kesesuaian pernyataan dari subyek penelitian dengan makna yang terkadnung dengan konsep - konsep dasar dalam penelitian tersebut. Kesimpulan dalam penelitian kualitatif dapat berupa deskripsi atau gambaran suatu objek yang sehingga setelah diteliti menjadi jelas.

\section{HASIL PENELITIAN DAN PEMBAHASAN}

\section{A. Deskripsi Hasil Observasi kegiatan pembelajaran}

Dari hasil pengamatan kegiatan pembelajaran yang berlangsung umumnya guru menggunakan pembelajaran secara langsung, namun sekarang guru harus melakukan pembelajaran secara online atau menggunakan alat komunikasi seperti handphone. Selain itu guru juga menggunakan media buku (LKS dan buku 
Tematik) dalam pembelajaran atau pun memberi tugas. Aktivitas siswa yang muncul pada umumnya memperhatikan guru dalam menjelaskan materi pembelajaran sehingga kondisi kelas dapat terkendali dan memungkinkan siswa mengikuti pembelajaran secara optimal dengan keadaan sekarang membuat para orang tua siswa ikut serta dalam mengikuti kegiatan pembelajaran untuk mendampingi anak-anaknya.

Model pembelajaran berbasis online pada pelaksaan pembelajaran mengajar data sebesar guru yang berperan aktif. Hal tersebut membuat siswa cenderung kurang aktif saat menerima pelajaran dikelas karena menggunakan alat media komunikasi (bandphone) banyak dari siswa yang sulit untuk mengerti pembelajaran berlangsung.

\section{B. Desain Pembelajaran}

Desain pembelajaran yang ada saat ini dipengaruhi atau dilandasi oleh teori belajar tertentu dan juga oleh pandangna manusia tentang kehidupan ini. Tujuan utama dari desain pembelajran dalah untuk menyediakan panduan atau pedoman bagi kita dalam merancang kegiatan belajar yang berkualitas bagi pembelajar. Prinsip dan langkah pengembangan pembelajaran menurut ( $V$ an den Akker dkk, 2005; Plomp \& Nieveen, 2010; McKenny \& Reeves, 2012) dalam buku (Putrawangsa, 2018) yang secara umum dapat digambarkan dalam tiga tahapan, yaitu sebagai berikut:

1. Tahapan analisis dan perumusan kerangka konseptual rancangan. Pada tahapan ini minimal terdiri atas kegiatan berikut ini:
a. Klarifikasi dan pendefinisian masalah
b. Analisis konteks rancangan
c. Perumusan tujuan dan kriteria rancangan
d. Perumusan proposisi/hipotesis rancangan

2. Tahapan perancangan dan pengembangan

3. Tahapan evaluasi sumatif

Perencanaan pembelajaran yang dilakukan oleh guru sebagian besar telah menyusun RPP. Dalam pembelajaran dikelas uraian aktivitas yang dilakukan oleh 
guru terbagi menjadi 3 kegiatan, yaitu kegiatan awal, kegiatan inti dan kegiatan akhir. Kegiatan awal memuat upaya yang dilakukan oleh guru untuk mendorong dan mengarahkan perhatian peserta didik mengikuti pembelajaran, selanjutnya kegiatan inti, guru menjelaskan materi pembelajaran kepada peserta didik serta pada kegiatan akhir guru memberikan kesimpulan berkenaan penjelasan materi pembelajran. Adapun aplikasi metode mengajar umumnya guru mengaplikasikan metode ceramah. Diakhir pertemuan pembahasan siswa diberikan tugas pembahasan materi pembelajaran guna untuk mengetahui kemajuan siswa maka dilakukan penilaian berupa test diakhir pertemuan. (Sudjarwo,1984:36) penjelasan tujuan instruksional khusus untuk membantu mendefinisikan arah pembelajaran serta sebagai petunjuk tentang materi pelajaran yang diperlukan.

\section{Perumusan tujuan pembelajaran}

Dari hasil wawancara kepada guru SDN SARAKAN 2 tujuan instruksional khusus yang dilakukan adalah : 1) memilih bahan ajar (materi pembelajaran); 2) memilih metode belajar banyak metode-metode yang bisa digunakan untuk mengajar anak-anak SD metode pada umumnya adalah Ceramah tapi metode yang membuat hati anak senang dengan pembelajaran menggunakan metode Bermain;3) melihat keadaan siswa ;4) tindakan, tindakan yang dimaksud adalah timbal balik terhadap pembelajaran jika berhasil, jika ada siswa yang kurang dalam pembelajaran berikan pengayaan kepada siswa atau memberi remedial khusus kepada anak yang memiliki nilai yang kurang. Indicator tujuan pembelajaran khusus dijabarkan dalam format ABCD (Audience, Behaviour, Condition dan Degree) terdapat kesenjangan yaitu perumusan hanya audience dan behavior. Tujuan Instruksional Khusus yakni satu-satunya dasar untuk merumuskan kisi-kisi percobaan, karena itu harus berisi unsur-unsur yang dapat menurunkan petunjuk kepada penyusun tes agar dapat mengembangkan tes yang benar-benar dapat mengukur perilaku yang terdapat di dalamnya (Suparman, desain instructional, 2014) bahwa unsur-unsur dalam tujuan instruksional khusus dikenal dengan $\mathrm{ABCD}$ yang berasal dari kata sebagai berikut:

$\mathrm{A}=$ Audience, $\mathrm{B}=$ Behavior, $\mathrm{C}=$ Condition, $\mathrm{D}=$ Degree. Audience adalah siswa yang akan belajar atau peserta didik, behavior adalah perilaku spesifik hang 
dimunculkan oleh siswa setelah selesai proses belajarnya dalam pelajaran tersebut, condition adalah kondisi atau batasan yang dikenakan kepada siswa atau alat yang digunakan siswa pada saat di tes (bukan pada saat belajar), dan Degree adalah tingkat keberhasilan siswa dalam mencapai perilaku tersebut.

Tujuan pembelajaran khusus merupaan perubahan tingkah laku hasil belajar atau kemampuan actual yang khusus/spesifik dan harus dapat ditampilkan atau diunjukkerjakan (performance). Hasil pembelajaran khusus yang ditampilkan harus dapat diamati dan diukur secara langsung oleh guru atau pengajar, karena tujuan pembelajaran harus dirumuskan dengan kata kerja dan operasional, misalnya membaca, menulis, menghitung, menggambar, menyebutkan, menjelaskan, memilih, membongkar, memasang, memotong, mengelas, merakit, menjahit, menghormati, menghemat, menepati, menerima, merawat. Kriteria yang baik untuk tujuan pembelajaran khusus seperti, berikut:

a. Menggunakan kata kerja yang operasional khusus

b. Berbentuk tingkah laku yang dapat ditampilkan dan diamati

c. Setiap tujuan pembelajaran khusus janya mengandung satu tingkah laku

d. Penampilan hasil belajar harus dapat diukur

Sesuai dengan pembahan diatas yang dimaksud dapat diukur seperti menggunakan Format $\mathrm{ABCD}$ (audience, behavior, condition, degree).

Biasanya dalam peraktik sehari-hari, perumusan TIK atau tujuan pembelajaran khusus hanya mengandung dua unsur komponen, yaiut komponen $\mathrm{A}$ dan $\mathrm{B}$. kadang-kadang dapat kita jumpai TIK menggunakan rumusan dengan tiga komponen $\mathrm{A}, \mathrm{B}$ dan $\mathrm{D}$, tetapi terlalu jarang orang merumuskannya secara lengkap dengan empat komponen A,B,C D karena dianggap terlalu sulit dan kurang praktis. Yang paling penting bagi pengembang inatruksional yang menulis TIK secara tidak lengkap menyadari bahwa kekurangan komponen $\mathrm{C}$ dan D itu akan menyebabkan kekurangpstian dalam penulisan tes di kemudian hari dan penafsiran terhadap hasilnya.

Selain menggunakan Format A, B, C dan D (atau format ABCD), masih ada cara perumusan lain, misalnya, teknik perumusan yang mengandung unsur proses 
belajar. Namun, cara perumusan lain tersebut tidak dibahas karena menghindari kerumitan teknis yang berlebihan. (Suparman, desain instructional, 2014).

Contoh:

Diberikan Gambar, Bahan dan Alat - alat

C

\section{$\underline{\text { Siswa-siswi SDN SARAKAN } 2 \text { dapat membuat }}$}

A

$\underline{\text { Sebuah gambar hewan-hewan sebanyak } 3 \text { hewan yang digambar }}$

$\mathrm{D}$

Jadi tidak selalu dirumuskan ABCD tapi bisa dirumuskan sesuai pengajar yang memberikan penugasan. Gunakan tujuan pembelajaran khusus sebagai acuan dalam memilih prosedur penilaian maupun menyusun alat evaluasi; tigkatkan pengetahuan teori dan keterampilan teknis yang diperlukan dalam mengembangkan tujuan pembelajaran khusus; lakukan review berulang kali rumusan-rumusan tujuan pembelajaran khusus setelah digunakan dengan menggunakan umpan balik dari hasil analisis terhadap hasil tes maupun ujian.

\section{Tujuan Instruksional meningkatkan keefektivitas proses belajar- mengajar}

Menurut Ely dan Gerlach (1971) dalam (Chomaidi \& Salamah, 2018), Tujuan instruksional di definisikan sebagai suatu perubahan tingkah laku atau hasil perbuatan yang memberikan petunjuk bahawa suatu proses belajar telah berlangsung. Jadi tujuan instruksional sangat membuat keefektivitasan karena tujuan instruksional ini dapat menjadi arah proses perkembangan instruksional karena didalamnnya ada rumusan pengetahuan, keterampilan dan sikap yang akan dicapai, sistem instruksional yang digunakan oleh guru atau pengajar sangat meningkatkan keefektifan.

Belajar dalam kondisi pertama dinamakan relevant learning; sedangkan belajar pada kondisi kedua dinamakan incidental learning (P.C. Duchatsel D.R Brown,1974). 
Efektifitas adalah kondisi efektif dari suatu usaha, yang dalam hal ini adalah tindakan pembelajaran yang dilakukan guru yang dibuktikan dengan prestasi belajar yang diperlihatkan siswa. Dengan demikian maka efektifitas adalah rasio antara hasil yang dicapai dnegan hasil yang diinginkan untuk dicapai. Dengan demikian maka suatu pembelajaran dikatakan efektif apabila tujuan yang dicapai sama dengan atau mendekati tujuan yang diingin dicapai siswa. Maka dapat dikategorikan efektif. Mengingat usaha apa yang diinginkan, maka dalam konteks pembelajaran jika siswa berhasil mencapai 8 atau 9 tujuan dari 10 tujuan yang ditetapkan guru, maka kondisi yang demikian yang dikatakan atau dapat digolongkan efektif.

Medley (1982) sebagaimana dikutip oleh (soekartawi, 1995) menyatakan bahwa peran guru atau pengajar sangat dominan dalam melakukan efektifitas pengajaran. Menurut karakteristik mengajar yang efisien ini ditentukan oleh:

a. Penampilan pengajar seperti personality, kedisiplinan, penguasaan bahan ajar dan persiapan mengajar.

b. Cara mengajarnya seperti urutan pengajaran, pemilihan model pengajaran, dan penggunaan alat bantu ajar

c. Kompetensi dalam mengajar sesuai dengan perkembangan disiplin keilmuan yang berkembang

d. Kemampuan mengambil keputusan secara bijaksana, misalnya dalam mengendalikan diskusi dan memberikan evluasi.

Efektifitas suatu pembelajaran merupakan suatu hal yang sangat penting dalam mencapai tujuan pembelajaran. Menurut Wragg dalam asep dan Abdul (2010:12) pembelajaran yang efektif adalah pembelajaran yang memudahkan siswa untuk mempelajari sesuatu yang bermanfaat seperti, fakta, keterampilan, nilai, konsep, dan bagaimana hiduo serasi dengan sesame atau suatu hasil belajar yang diinginkan. Senada dengan Wragg, Nieveen dalam Iif dan Sofan (2011:10) berpendapat bahwa pembelajaran yang efektif adalah pembelajaran yang secara operasional memberikan hasil sesuai dengan yang diharapkan. Selanjutnya (saadi, 2013) juga mengemukakan bahwa pembelajaran dikatakan efektif jika tujuan instruksional khusus yang direncanakan banyak tercapai. 


\section{E. Manfaat Pembelajaran}

Manfaat instruksional khususnya ini dapat menjadi petunjuk dan memudahkan guru untuk memilih dan menyusun bahan ajar dan memudahkan dalam mengkomunikasikan maksud dalam belajar-mengajar kepada siswa sesuai dengan RPP yang sudah dirancang oleh guru sudah menentukan pokok bahasan, mengalokasikan waktu dan alat yang digunakan saat pembelajaran. Pentingnya pelaksanaan pelatihan guru sebagai upaya peningkatan mutu guru akan memiliki makna dan berkontribusi pada mutu pendidikan. (Suryanto, 2001) mengatakan bahwa selama kemampuan professional guru belum bisa mencapai tataran ideal, guru harus mendapatkan pelatihan yang terus menerus. Menjadikan sekolah sebagai organisasi belajar untuk meningkatkan kapasitas guru. (senge, 1994) mengemukakan organisasi belajar adalah organisasi tempat dimana anggotaanggotanya terus menerus meningkatkan kapasitasnya untuk meningkatkan pola pikir baru dengan mengembangkan aspirasi kreatif. Menurut Nana Syaodih Sukmadinata dalam buku (Rahman, 2020) mengidentifikasi 4 manfaat dari tujuan pembelajarann, yaitu:

a. Memudahkan dalam mengkomunikasikan maksud kegiatan belajar mengajar kepada siswa, sehingga siswa dapat melakukan perbuatan belajarnya secara lebih mandiri

b. Memudahkan guru memilih dan menyusun bahan ajar

c. Membantu memudahkan guru menentukan kegiatan belajar dan media pembelajaran

d. Memudahkan guru mengadakan penilaian

Dalam permendiknas RI No. 52 Tahun 2008 tentang Standar Proses disebutkan bahwa tujuan pembelajran memberikan petunjuk untuk memilih isi mata pelajaran, menata urutan topik-topik, mengalokasi wakti, petunjuk dalam memilih alat-alat bantu pengajaran dan prosedur pengajaran, serta menyidiakan ukuran (standar) untuk mengukur prestasi belajar siswa

\section{F. Strategi dalam instruksional khusus}


Dari hasil wawancara Menurut guru SDN SARAKAN 2 mengatakan bahwa Strategi dalam instruksional khusus menjadi rumusan yang menjelaskan apa yang ingin dicapai dan apa yang menjadi akibat setelah melakukan pembelajaran.

Sebab itu mengapa strategi instruksional itu penting? sebab guru tidak akan mudah menentukan materi atau toppik pembelajaran yang akan dibahas bersama siswa apabila tidak mngetahui tujuan pembelajaran yang akan dicapai.

(Carey, 2009) mengatakan bahwa "instructional strategy is used generallyto cover the various aspects of choosing a delivery system, sequencing and grouping clusters of content, describing learning components that will be included in the instruction, establishing lesons structures and selecting media for delivering instruction”.

Strategi pembelajaran secara umum digunakan untuk menemukan berbagai aspek untuk memilih system penyampaian, penginstrukturan dan pengelompokkan kelompok konten atau isi pembelajaran menggambarkan komponen pembelajaran, menentukan bagaimana peserta didik akan dikelompokkan selama proses pembelajaran berlangsung, membangun struktur pembelajaran, dan memilih media yang tepat untuk kegiatan pembelajaran.

Menurut Dick, Carey and Carey (2009:178-179) komponen-komponen belajar dalam strategi pembelajaran terdiri dari 5 tahap kegiatan yaitu:1) tahap awal (preinstructional activities); 2) penyajian isi (content presentation) ;3) partisipasi peserta pelatihan (learnerparticipation); 4) penilaian (Assesment) ;5) kegiatan tindak lanjut (follor-through activites).

Startegi instruksional berkenaan dengan pendekatan dalam mengelola isi dan proses instruksional secara komprehensif untuk mencapai satu atau sekelompok tujuan instruksional. Di dalamnya terintegrasi berbagai komponen yang meliputi urutan kegiatan pembelajaran, garis besar isi, metode, media \& alat dan waktu belajar (Dalam menit). (Suparman, Desain Instruksional Modern, 2012). 


\section{G. Penerapan pembelajaran untuk siswa-siswi yang memiliki kekurangan}

Jika siswa memiliki kekurangan guru atau pengajar harus memberikan dampingan kepada anak tersebut. sebelum itu kita harus mengetahui kekurangan apa yang ada pada dirinya atau kesuliatan apa yang dialami siswa dengan cara guru menggunakan banyak media yang digunakan saat pembelajaran akan membuat siswa merasa senang dan mudah memahami pembelajran. Contohnya: gambargambar yang sudah dibuat. Jika diberi benda konkret siswa yang memiliki kekurangan lebih mudah menerima pembelajaran. Manfaat instruksional khususnya ini dapat menjadi petunjuk dan memudahkan guru untuk memilih dan menyusun bahan ajar dan memudahkan dalam mengkomunikasikan maksud dalam belajar-mengajar kepada siswa sesuai dengan RPP.

Sebagai pengajar atau guru harus memiliki strategi dasar belajar mengajar yang mleiputi hal-hal berikut:

1. Mengidentifikasi serta menetapkan tingkah laku dan kepribadian anak didik sebagaimana yang diharapkan sesuai tuntutan dan perubahan zaman

2. Mempertimbangkan dan memilih system belajar mengajar yang tepat untuk mencapai sasaran yang akurat

3. Memilih dan menetapkan prosedur, metode dan teknik belajar mengajar dan dianggap paling tepat dijadikan pegangan guru dalam menunaikan kegiatan mengajar

Jika siswa atau peserta didik memiliki kekurangan yang malas belajar didalam kelas guru atau pengajar maka membuat strategi yang dilakukan oleh guru kepada peserta didiknya strategi yang diterapkan:

1. Menciptakan kesiapan belajar

Secara fisik sisiwa harus mempersiapkan kondisi tubuhnya dan selain itu siswa harus berada dalam kondisi siap belajar agar rasa ketertarikan belajar pun muncul, periksa peralatan-peralatan belajar.

2. Memberikan motivasi

Berikan dukungan kepada siswa agar terdorong dalm pembelajaran, berikan penghargaan, bukan penghargaan berupa barang, makanan 
ataupun uang. Siswa akan termotivasi bila diberi pujian d yang dia lakukan ketika pembelajaran sedang berlangsung walaupun hanya memuji tulisannya, kefokusan dalam memperhatikan guru sedang menjelaskan.

3. Mengurangi marah yang berlebihan

Ketika seorang guru menghadapi peserta didiik yang bermasalah dengan cara marah apalagi sampai tidak mendidik hanya akan menambah rasa malas peserta didik untuk mengikuti proses pembelajran di kelas bahkan dapat membuat peserta didik ketakutan dan pada akhirnya mereka tidak mau lagi dating ke sekolah atau dalam keadaan PJJ (pembelajaran Jarak Jauh atau online) siswa tidak mau Hadir dalam pembelajaran.

\section{KESIMPULAN}

Dari hasil pengamatan kegiatan pembelajaran dilakukan secara online. Model pembelajran berbasis online pada pelaksanaan pembelajaran sebagain guru yang berperan aktif. Perencanaan pembelajaran yang dilakukan oleh guru sebagaian besar telah menyusun rpp. Tujuan instruksional khusus yang dilakukan adalah: 1) memilih bahan ajar (materi pembelajaran); 2) memilih metode belajar banyak metode-metode yang bisa digunakan untuk mengajar anak-anak SD ;3) melihat keadaan siswa ;4) tindakan. Tujuan instruksional sangat membuat keefektivitasan karena tujuan instruksional ini dapat menjadi arah proses perkembangan instruksional karena didalamnnya ada rumusan pengetahuan, keterampilan dan sikap yang akan dicapai, sistem instruksional yang digunakan oleh guru atau pengajar sangat meningkatkan keefektifan. Strategi dalam instruksional khusus menjadi rumusan yang menjelaskan apa yang ingin dicapai dan apa yang menjadi akibat setelah melakukan pembelajaran. Strategi dalam instruksional khusus sangat penting karena guru tidak akan mudah menentukan materi atau toppik pembelajaran yang akan dibahas bersama siswa apabila tidak mngetahui tujuan pembelajaran yang akan dicapai. 


\section{DAFTAR PUSTAKA}

Anggito, A. (2018). Metodologi penelitian kualitatif. In Metodologi penelitian kualitatif (p. 19). Jawa Barat: CV Jejak.

Carey, D. c. (2009). the systematic design of instructional. new jersey: pearson.

Chomaidi, \& Salamah. (2018). PENDIDIKAN DAN PENGAJARAN STRATEGI PEMBELAJARAN SEKOLAH. Jakarta: Grasindo.

Edi, F. R. (2009). Teori Wawancara Psikodiagnostik. In Teori Wawancara Psikodiagnostik (p. 1). Yogyakarta: Leutikaprio.

Putrawangsa, S. (2018). DES AIN PEMBELAJARAN (Design Research sebagai Pendekatan Desain Pembelajaran). Mataram: Reka Karya Amerta (Rekarta).

Rahman, N. (2020). Desain kompetensi dan tujuan pembelajaran. Visual publish.

saadi. (2013). pembelajaran yang efektiiftas. Jawa Barat: japendi press.

Sanjaya, W. (2009). kurikulum dan pembelajaran. Jakarta: Kencana ,Prenada Media Group.

Semiawan, C. R. (2010). Metode Penelitian Kualitatif. Jakarta: Grasindo.

senge, p. M. (1994). The Fifth Discipline. United states of america: publishing group.

Setyosari, P. (2013). Metode Penelitian dan Pembelajaran. Jakarta: Kencana.

Setyosari, P. (2020). Desain Pembelajaran. Jakarta Timur: Bumi Aksara.

soekartawi. (1995). meningkatkan efektifitas mengajar. Jakarta: Pustaka Dunia Jaya.

Suparman, A. (2012). Desain Instruksional Modern. Jakarta: Erlangga.

Suparman, A. (2014). desain instructional. jakarta: universitas terbuka.

Suryanto. (2001). Refleksi dan Reformasi pendidikan indonesia memasuki millenium III. Yogyakarta: Adicita.

Wragg. (2010). Efektifitas. In A. d. Abdul, pembelajaran yang efektif (p. 12). jakarta: pustaka press.

wragg, N. (2011). efektifitas dalam mengajar. In s. Iif, efektifitas dalam mengajar (p. 10). jakarta: pustaka jaya. 